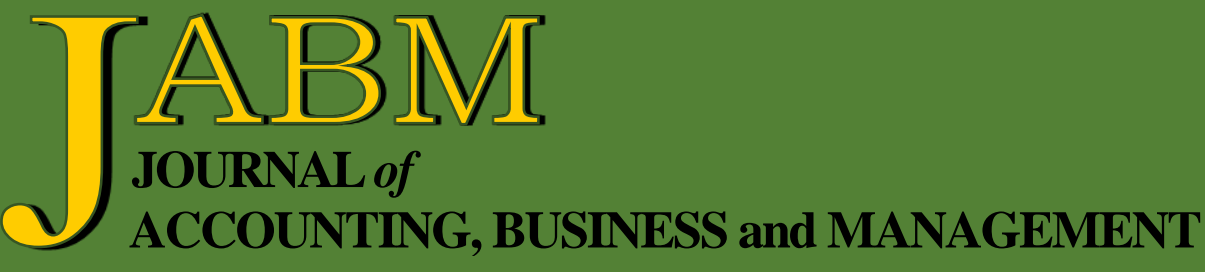

Towards Understanding the Effects of Web 2.0 at the Project Level Knowledge Management on Projects' Success

Anupam Kumar Nath

Sticky Costs and Expenses are not Alike: Mexican Reality

Luis Felipe Llanos Reynoso, César Vela-Beltrán-del-Río, and

José Luis Martínez-Berrones

Business Sustainability Through Environmental and Operational Management in Five Star Hotels in Amman, Jordan

Haitham Abdelrazaq, Taghreed Aljaffal, Pheroza Daruwalla, and

Karina Wardle

Impacts of Asset Utilization, Market Competition and Market

Distance on Stock Returns

Jeanne-Claire Patin, Matiur Rahman, and Muhammad Mustafa

Accounting Conservatism, Information Asymmetry and

Cash Holdings

Walid Shehata and Ahmed Rashed

An Investigation of the Relationship between Corporate Social Responsibility and Corporate Financial Performance in Egypt: The Mediating Role of Information Asymmetry

Nancy Mohamed and Ahmed Rashed

The Impact of Regulatory Capital and Bank Characteristics on the Relationship between Bank Competition and Risk Taking in the Banking System

Eman Abdel-Wanis

Firm Size, Firm Age, and Firm Profitability: Evidence from China Md. Jahidur Rahman and Liu Yilun 
Journal of Accounting, Business and Management vol. 28 no. 1 (2021) 73-86

\title{
An Investigation of the Relationship between Corporate Social Responsibility and Corporate Financial Performance in Egypt: The Mediating Role of Information Asymmetry
}

\author{
Nancy Mohamed* \\ Ahmed Rashed ${ }^{\dagger}$
}

\begin{abstract}
The aim of this paper is to investigate the impact of corporate social responsibility (CSR) on corporate financial performance (CFP) through information asymmetry (IA) as a mediator. The study involved the whole sectors in the listed companies on Egx100 excluding Financial sectors (banks and financial services) from 2013-2017 using smart PLS (Partial Least Square). CSR is measured using CSR index, while Share turnover ratio is used to measure IA. CFP is divided into three indicators: ROA, ROE and ROS. The Structural model assessment reveals that CSR has a positive and significant effect on CFP. This means that those listed companies engaged in CSR activities achieved better financial performance than non- CRS companies. The CSR proved to have a negative and significant effect on the IA. This shows that CSR activities lead to decreased IA. Finally, this research found that CSR activities will improve CFP through IA.
\end{abstract}

Keywords: corporate social responsibility (CSR), corporate financial performance (CFP), and information asymmetry (IA).

\section{INTRODUCTION}

Recent financial crisis and scandals, increased competition, and more demanding stakeholders have led to radical changes, not only at the corporate level, but also at the society level. Most firms begin to broaden their strategies by integrating Corporate Social Responsibility (CSR) initiatives. By doing so, the firms shifted their main goal from maximizing the benefits to stockholders only to maximizing the benefits to stakeholders (Becchetti et al., 2012). As a result, Egyptian firms started to focus on CSR initiatives in order to gain their stakeholders' trust, to enhance their competitive position, and therefore, achieving better financial performance (Peloza \& Jingzhi, 2011; Sun, 2012; and Bhalla, 2013).

CSR defined in the literature in many different ways, general and specific definitions. Relch (1998) defined CSR generally as: "the term used to assert or assign leadership responsibility of the businessman with respect to culture of the community". Most recently, Garg (2016) defined CSR as: "CSR is how companies manage their business processes to produce an overall positive impact on society". Cui et al. (2018) stated that: "CSR generally refers to serving people, communities, and the environment in ways that go above and beyond what is legally required of a firm". More specifically, Carroll (1991) defined CSR as: "a combination of economic responsibilities, legal responsibilities, ethical responsibilities, and philanthropic responsibilities metaphorically

\footnotetext{
* Accounting Department, Cairo University, Cairo, Egypt. E-mail: Nancy_M_Mahmoud @foc.cu.edu.eg.

† Finance Department, Faculty of Commerce, Cairo University, Cairo 12613, Egypt. E-mail: ahmed_rashed@foc.cu.edu.eg.
} 
through a pyramidal shape". Sundaralingam and Yazdanifard (2014) stated that: "corporate social responsibility is about attracting traders and further stakeholders and group up with them to further effectively cope with possible jeopardizes and build reliability and dependency from the group".

Based on the above definitions, CSR can be defined as the processes implemented by corporations to serve the society as a whole, not just maximizing profits to the shareholders. CSR in Egypt is still in the development phase. The Egyptian government tries to attract foreign investments by considering CSR as a main component of their national competitive strategies. El-Shayeb (2016) stated that the Egyptian environment has started many important steps to promote CSR practices. One of the most important steps toward CRS improvement is the establishment of the Egyptian corporate responsibility center (ECRC) by the ministry of investment (MOI). The establishment of ECRC has improved the awareness of CSR issues and has assumed a leadership role in the region in this respect. Another important step to promote CSR is the establishment of a special corporate environmental, social, and governance index (ESG) on 2010. This index was established to motivate companies to become more transparent and to disclose their governance, social and environmental practices more clearly to increase their competitive advantage. (Razek, 2014). Egyptian firms are trying to cope with these efforts in order to improve their CSR practices.

Information about CSR performance is particularly important to investors (Cho et al., 2013). Previous studies found that investors use CSR performance information in their investment decisions (Cohen et al., 2011; Cruise, 2011). Therefore, firms attempt to reduce information asymmetry (IA) by providing voluntary disclosures about activities related to CSR. Fieseler (2011) argued that CSR activities disclosure can increase the flow of information from management to outside investors and can improve stock price informativeness. Cho et al. (2013) found an inverse relationship between a firm's engagement in CSR and its level of IA. Consistent with previous studies, CSR activities reduce IA; however, there is little empirical evidence examined the relationship between CSR and IA, especially in the Egyptian environment. Prior studies have discussed either the impact of CSR on IA or the relationship between CSR and CFP.

This paper aims to contribute to the literature by studying (1) the direct effect of CSR on IA (2) the direct relationship between CSR and CFP and (3) the impact of CSR on CFP through IA. To the best of our knowledge, this is the first study to examine the CSR- CFP relationship through considering the effect of IA as a mediator in this relation in the Egyptian environment.

The rest of the paper is organized as follow; section two presents a summary of previous studies and hypothesis development; section three develops the research model; section four explains the empirical methodology adopted in this research; section five provides a summary of descriptive statistics and empirical estimations, section six includes an analysis and discussion of empirical results and section seven concludes the paper.

\section{LITERATURE REVIEW AND HYPOTHESES DEVELOPMENT}

\subsection{Corporate Social Responsibility (CSR) and Corporate Financial performance (CFP)}

CSR becomes one of the most important issues in today's business practices. Several studies were conducted to examine the direct relationship between CSR and CFP. Griffin and Mahon (1997) examined the association between CSR and CFP of 
seven firms operating in chemical industry. They found that superior financial performance was associated with high CSR. Using data extracted from the largest 500 US companies, Verschoor (1998) found that those companies committed to their stakeholders with a code of professional conduct achieve higher financial performance than non- committed companies. On analyzing US banks, Simpson and Kohers (2002) revealed that a company can be responsible to the society and improve its financial performance at the same time. Sun (2012) stated that CSR activities lead to enhancing company- stakeholders relationship. A firm that is socially responsible may face less labor problems, less government concerns related to the environment and less complains from the community.

Samy et al. (2010) found that out of the 20 selected companies, only 4 achieved all six guidelines of CSR. In addition, the study revealed a positive but weak relationship between CSR and Earnings per share (EPS) as a proxy measure of profitability. Using data on more than 900 companies over nine years in seven CSR areas (environment, corporate governance, community, employees, diversity, human rights, and product quality), Boesso et al. (2015) showed that CSR companies are more likely to improve their financial performance through linking CSR initiatives with stakeholders' preferences, and strategically, allocating organizational resources to these initiatives.

Moreover, Lu et al. (2018) found that CSR activities do not improve financial performance in the short-run, but they improve CFP in the long-run. The results indicated that the effect of CSR is not immediate on CFP and it may take time to convert CSR outcomes into material benefits.

On the other hand, Cochran and Wood (1984) found weak association between CSR and CFP. Using a time series fixed effects approach, Nelling and Webb (2009) found a weak relationship between CSR and financial performance. They found that CSR activities are driven by unobservable firm characteristics more than by financial performance. Furthermore, McWilliams and Siegel (2000) and Saxena and Kohli (2012) reported that CSR does not affect CFP of socially responsible firms.

The analysis of previous studies reported in consisted results (positive, negative and neutral) concerning the relationship between CSR and CFP. This contradiction may be due to the nature of industry sector in which the companies operate; the CSR stage in the country being studied, the time period covered by the study (Garg, 2016). Therefore, the following hypothesis is formulated to examine the effect of CSR on CFP in Egypt:

$\mathbf{H}_{1}$ : corporate social responsibility (CSR) practices are positively associated with corporate financial performance (CFP).

\subsection{Corporate Social Responsibility (CSR) and Information Asymmetry (IA)}

When reviewing the literature concerning the relationship between CSR and IA, several studies were analyzed. Gelb and Strawser (2001) found that high CSR firms tend to disclose more information than low ones. This could be justified due to the responsibility sense of CSR firms to their stakeholders. Cho et al. (2013) measured IA using bid- ask spread as a proxy measure. They found that IA is reduced in CSR firms. Firms' transparency is increased as a result of increasing CSR disclosures. Firms with good performance want to highlight their good performance to their stakeholders, and those with low performance want to explain the reasons of their low performance. Therefore, IA would be reduced. In addition, Lu and Chueh (2015) found negative association between CSR and IA, measured using bid- ask to spread as a proxy. They 
revealed that those companies that pay more attentions on CSR would reduce the degree of IA compared with those which males less efforts in CSR practices.

Moreover, Cui et al. (2018) found that the negative association between CSR and IA is more significant in high-risk companies than in low-risk ones. Managers of highrisk firms make significant efforts to increase non-financial information disclosures through CSR practices in order to eliminate adverse investors' selection. Based on the above discussion, it is clear that most studies that examined the effect of CSR on IA were conducted in developed countries; therefore, the following hypothesis is formulated to examine the effect of CSR on IA in Egypt:

$\mathbf{H}_{2}$ : corporate social responsibility (CSR) practices are negatively associated with the level of information asymmetry (IA).

\subsection{Corporate Social Responsibility (CSR), Information Asymmetry (IA), and Corporate Financial performance (CFP)}

Prior studies have discussed either the impact of CSR on IA or the association between CRS and CFP. To the best of our knowledge, no study has examined the effect of IA as a mediator on the relationship between CSR and CFP. Hence, this study is designed to examine the indirect effect of CSR on CFP through IA in the Egyptian context. Therefore, the following hypothesis is formulated:

$\mathbf{H}_{3}$ : the effect of corporate social responsibility (CSR) practices on corporate financial performance (CFP) is mediated by the level of information asymmetry (IA).

\section{RESEARCH SAMPLE AND METHODOLOGY}

\subsection{Proposed Model}

The relationships among the study main variables and the proposed model are the following figure:

Figure 1

Research Model

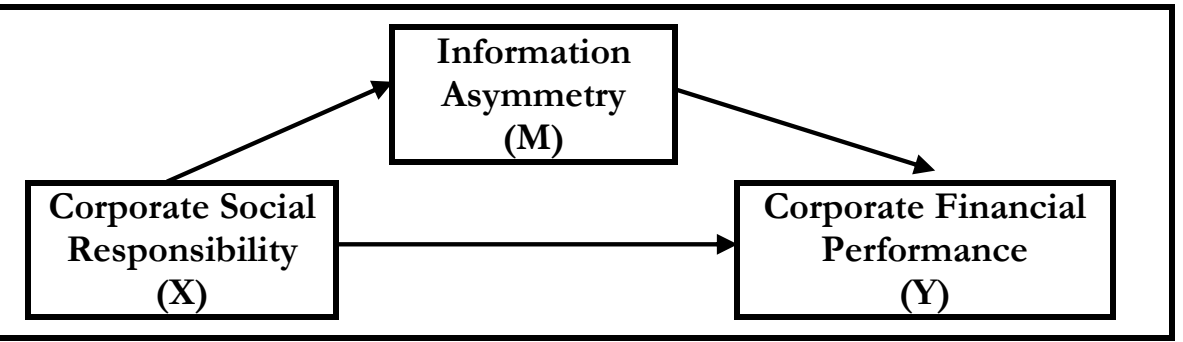

3.2. Methodology

\subsubsection{Variables Measurements}

1). Corporate Social Responsibility (CSR)

CSR is the independent variable, which is measured using the "S\&P/EGX ESG" Index. "S\&P/EGX ESG" Index is considered the key source for evaluating CSR practices of Egyptian firms. This index offers published data related to Egyptian firms' CSR activities. The index consists of 30 companies selected from the most active 100 companies listed on the Egyptian Stock Exchange according to their environmental, social responsibility and governance standards. All the 100 listed companies are screening carefully in order to give each firm a weight related to their environmental, social and governance (ESG) indicators. 
The information used to generate each company's CSR weight is obtained from each company's annual reports, its financial statements, its Web site, and the information disclosed in the Egyptian Stock Exchange Market. If the company discloses positive information, it gets one point. In the case of disclosing additional information, the company gets 3 points, in case the disclosure is positive. This study uses each company's weight generated by the S\&P/EGX ESG” index as a measure of their CSR practices. However, those companies that are included in EGX 100 but not included in "S\&P/EGX ESG" Index will take a value of (0).

This measure was selected rather than CSR disclosure index because social responsibility among Egyptian firms remains in its infancy and the disclosure of these social activities still occasional and voluntary. In addition, "S\&P/EGX ESG" Index is considered the main source of information to evaluate CSR practices of Egyptian firms.

\section{2). Information Asymmetry (IA)}

IA is the mediator variable. It plays an important role in capital markets because of its impact on stock liquidity, which in turn affects the asset pricing and cost of capital (Abad et al., 2018). However, IA is not observable; therefore, the measurement of the level of IA related to a specific firm is a difficult task.

Previous studies have suggested several proxies to measure IA, such as the number of analysts following the firm, institutional and insider ownership, firm size, firm age, the volume of trade in shares of the firm, bid-ask spread, PIN score and stock return volatility. One of the most acceptable measure of IA in the literature is trading volume in a firm's shares (liquidity) measured by share turnover ratio (Bartov \& Bodnar, 1996; Leuz \& Verreccchia, 2000; and Petersen \& Plenborg, 2006). Therefore, IA in this study is measured using trading volume. Trading volume or turnover ratio is selected because it shows that some investors are willing to sell shares and other investors have the willingness to buy. Actively traded shares of a specific firm are the consequence of reduced IA. In contrast, increasing IA could result in lowering the share turnover because those investors with little information are not willing to buy or sell in these shares. Consistent with Bartov and Bodnar (1996) and Chan and Faff (2003), shares turnover ratio is calculated using the following formula:

$$
\text { Share Turnover }=\frac{\text { Average Daily Volume Traded }}{\text { Average Number of Shares Outstanding }} \ldots
$$

\section{3). Corporate Financial Performance (CFP)}

CFP is the dependent variable. There is a broad range of measures related to CFP. Cochran and Wood (1984) classified CFP measures into two categories; investor returns and accounting returns. Investor returns are concerned with measuring financial performance from the stockholder's point of view such as the price per share. On the other hand, accounting returns are concerned with analyzing the earnings ability to respond to different managerial policies such as, earnings per share. Consistent with Matin et al. (2011), Islam et al. (2012), Nollet et al. (2016) and Rodriguez-Fernandez (2016), this paper measures CFP from the accounting perspective, therefore, return on assets (ROA), return on equity (ROE), and return on sales (ROS) are used to measure CFP. ROA is measured using the ratio of net income to total assets. ROE is measured using the ratio of net income relative to equity capital. ROS is calculated using the ratio of net income to total sales.

\subsection{Sample Selection and Data collection}

The initial sample selected for this study includes companies that are listed on EGX 100 for five years from 2013 till 2017. These five years are selected as they 
represent the most recent five years on which "S\&P/EGX ESG" Index lists were available. The sample consisted of 395 annual firm observations from which 80 Firm Listed on EGX 100. The observations related to banks and other financial institutions are excluded due to their different disclosure requirements.

While, the final sample of the current study satisfied the following criteria; not including financial institutions due to their different disclosure requirements, and no missing financial statements during the testing years 2013 till 2017. Therefore, the final sample consists of 395 companies for the five years. This sample size is considered large enough to provide viable statistical analyses. Secondary data sources are used to gather the data related to CSR, IA and CFP. Data on CSR has been collected from "S\&P/EGX ESG" Index; however, data on IA has been obtained from Egypt for information dissemination company (EGID), a subsidiary of the Egyptian Stock Exchange Market. Data related to CFP has been collected from the consolidated annual reports of the sample firms. The annual reports used were ended on June 30 or December 31 as the indicator for the report to be an annual one, instead of a semiannual or a quarterly report.

Those annual reports are obtained from the Egyptian company for information dissemination (EGID). Data needed for CSR variable was obtained from "S\&P/EGX ESG" Index list ranking released by Egyptian corporate responsibility center (ECRC) for years 2013 till 2017. These lists were available from two websites; ECRC and Egyptian stock exchange. Table 1 summarizes the independent, mediator and dependent variables, their proxy measures, and the different sources of data.

Table 1

Variables Measurements, Proxies and Sources

\begin{tabular}{|c|c|c|c|}
\hline Variables & Abbreviation & Proxies Measures & Data Source \\
\hline $\begin{array}{l}\text { Independent } \\
\text { Variable }\end{array}$ & CSR & $\begin{array}{l}\text { Companies that is on S\&P/ } \\
\text { EGX ESG index would take } \\
\text { their ranking weight while, the } \\
\text { companies that are included } \\
\text { in EGX } 100 \text { and not included } \\
\text { on S\&P/EGX ESG index } \\
\text { would take a value of }(0) \text {. }\end{array}$ & $\begin{array}{l}\text { S\&P/EGX } \\
\text { ESG" index }\end{array}$ \\
\hline $\begin{array}{l}\text { Mediator } \\
\text { Variable }\end{array}$ & IA & Shares Turnover & EGID List \\
\hline $\begin{array}{l}\text { Dependent } \\
\text { Variable }\end{array}$ & CFP & ROA, ROE and ROS & $\begin{array}{l}\text { Financial } \\
\text { Statements }\end{array}$ \\
\hline
\end{tabular}

\section{DATA ANALYSIS, DISCUSSION AND RESULT}

\subsection{Data Analysis}

Table 2 presents the thirteen sectors listed in the EGX 100 in Egypt after excluding companies of the financial sector (banks and financial services companies). Table 2 indicates that the majority of the sample operates in real estate sector $(24.56 \%)$, then Food and Beverages sector approximately (18.99\%) then Building Material and Construction with a percentage of $(13.16 \%)$ then industrial goods, services and automobiles approximately $(10.63 \%)$, while minority of sample operates in media and oil and gas sectors approximately $(0.76 \%, 2.86 \%)$ respectively. 
Table 2

Sample of the Relevant Sectors

\begin{tabular}{lcc}
\hline \multicolumn{1}{c}{ Sector } & Frequencies & Percent \\
\hline A- Basic Resources & 15 & 3.80 \\
B- Building Material and Construction & 52 & 13.16 \\
C- Chemicals & 24 & 6.08 \\
D- Food and Beverages & 75 & 18.99 \\
E- Healthcare and Pharmaceuticals & 9 & 2.28 \\
F- Industrial goods, services and Automobiles & 42 & 10.63 \\
G- Media & 3 & 0.76 \\
H- Oil and Gas & 7 & 1.77 \\
I- Personal and Household Products & 29 & 7.34 \\
J- Real Estate & 97 & 24.56 \\
K- Tourism and Entertainment & 13 & 3.29 \\
L- Travel \& leisure & 10 & 2.53 \\
M- Telecommunication & 19 & 4.81 \\
\hline Total & 395 & $100 \%$ \\
\hline
\end{tabular}

Source: data processed 2019.

Table 3 presents the descriptive statistics of the whole variables. CSR index during 2013-2017 ranged from $0.00(0 \%)$ to $0.021(2.1 \%)$ with a mean value of 0.004 $(0.4 \%)$, meaning that there is a low variation of CSR levels across the companies with standard deviations of (0.005). The lowest CSR index of $(0 \%)$ was shown by the firms with no CSR index in a certain year.

\section{Table 3}

Descriptive Statistic

\begin{tabular}{lccccc}
\hline Variable & Obs. & Mean & Std. Dev. & Min. & Max. \\
\hline CSR & 395 & 0.004 & 0.005 & 0.00 & 0.021 \\
IA & 395 & 0.004 & 0.002 & 0.00 & 0.012 \\
ROA & 395 & 0.042 & 0.032 & 0.00 & 0.146 \\
ROE & 395 & 0.083 & 0.065 & 0.002 & 0.318 \\
ROS & 395 & 0.164 & 0.155 & 0.00 & 0.831 \\
\hline
\end{tabular}

Source: data processed 2019.

IA ranged from $0.00(0 \%)$ to $0.012(1.2 \%)$ with a mean value $0.04(0.4 \%)$ and standard deviation (0.002). The decrease in IA was shown by the companies with no IA during the period of 2013-2017 in the EGX 100. CFP was measured using ROA, ROE and ROS ratios. ROA ratio of 2013-2017 ranged from $0.00(0 \%)$ to $0.146(0.146 \%)$ with a mean value $0.042(4.2 \%)$ and standard deviation $(0.032)$. ROE ratio ranged from $0.002(0.2 \%)$ to $0.318(31.8 \%)$ with a mean value $0.083(8.3 \%)$ and standard deviation (0.065). ROS ratio ranged from $0.00(0 \%)$ to $0.831(0.83 .1 \%)$ with a mean value 0.164 $(16.4 \%)$ and standard deviation (0.155). The highest performance indexes indicated increase corporate profitability within the entire period in the companies that are listed on EGX 100.

Table 4 indicates the validity and reliability of the whole variables. According to the value of the loading factors (AVE), the whole indicators (CSR, IA and CFP) are higher than 0.50 which means that there is a convergent validity and the indicators were valid. Also, the reliability (Cronbach alfa) of CSR, IA and CFP are higher than 0.70 which means that there is a possibility of relying on these indicators to measure the variables of the study in general. 
Table 4

Construct Validity and Reliability

\begin{tabular}{lccc}
\hline Construct & $\begin{array}{c}\text { Average Variance } \\
\text { Extracted (AVE) }\end{array}$ & Composite Reliability & Cronbach Alfa \\
\hline CSR & 1.000 & 1.000 & 1.000 \\
IA & 1.000 & 1.000 & 1.000 \\
CFP & 0.796 & 0.902 & 0.869 \\
\hline
\end{tabular}

Source: data processed 2019.

Figure 2

Measurement Model

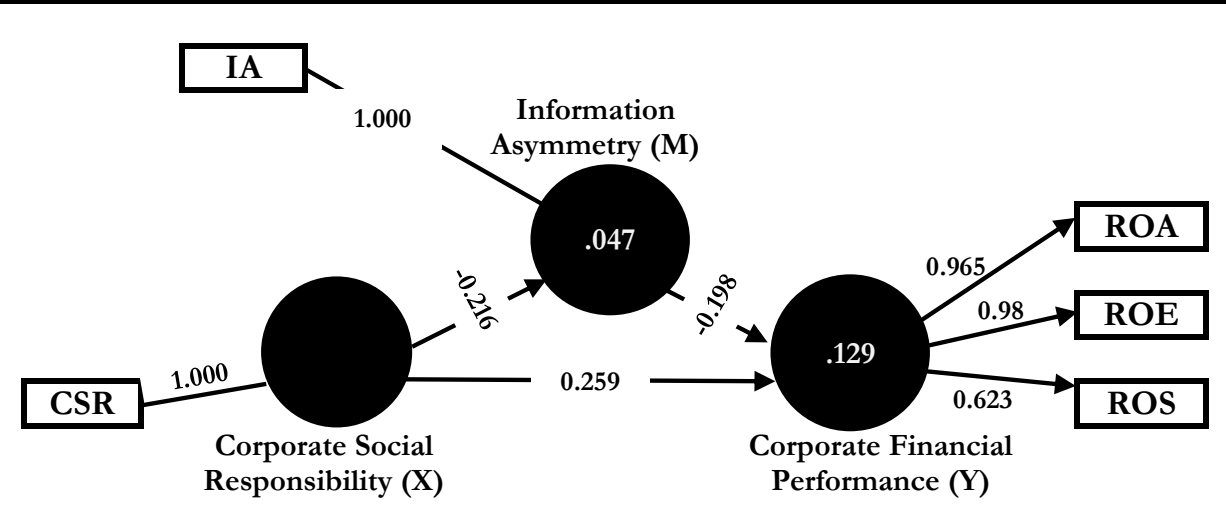

Table 5 presents the cross-loading values of each indicator, showing that all indicators comprising each variable met the discriminant validity because it had the greatest outer loading value for the variable it formed only, not for other variables. The whole indicators are a high degree of confidence and stability.

Table 5

Discriminant Validity

\begin{tabular}{lccc}
\hline Construct & CSR & IA & CFP \\
\hline CSR & 1.000 & & \\
IA & -0.217 & 1.000 & \\
CFP & 0.302 & -0.254 & 0.872 \\
\hline
\end{tabular}

Source: data processed 2019.

Table 6 shows that the R-square of the IA obtained 0.047 (4.7\%), indicating that $4.7 \%$ of the IA was affected by CSR. Meanwhile, the remaining $95.3 \%$ was affected by other variables (not involved in this research). Furthermore, Table 6 also suggests that the R-square of the CFP was 0.129 . This indicates that $12.9 \%$ of the CFP was affected by the CSR and IA. Meanwhile, the remaining $87.1 \%$ was influenced by other variables which were not studied in this research.

Table 6

R-Square Value

\begin{tabular}{lc}
\hline Constructs & R-Square \\
\hline IA & 0.047 \\
CFP & 0.129 \\
\hline
\end{tabular}

Source: data processed 2019. 


\subsection{Research Discussion}

\subsubsection{The Effect of Corporate Social Responsibility on Corporate Financial Performance}

The results of the first hypothesis explained above show that the relationship between the CSR and CFP was positive and significant, indicated by the path coefficient value of 0.259 and t-value of 5.252 Thus, it can be said the results are in line with the first hypothesis.

In addition, the positive path coefficient value 0.259 indicates that the relationship between the two variables is in the same direction, indicating that increasing CSR practices by companies will lead them to better CFP. The findings are consistent with the theoretical logic of the agency cost.

\subsubsection{The Effect of Corporate Social Responsibility on Information Asymmetry}

The results of the second hypothesis suggest that the relationship between CSR $(\mathrm{X})$ and the IA (M) obtained a path coefficient value of -0.216 with $\mathrm{t}$-value of 4.793 . These results indicate that the CSR significantly influenced the IA, supporting the second hypothesis. The negative path coefficient value of -0.216 suggests that the relationship between the two variables is not in the same direction, meaning that increasing CSR practices will decrease IA proxied by the Share Turnover, but it will occur at the t-value of 4.793 or higher than the ttable of 1.96. This finding is consistent with Gelb and Strawser (2001), Cho et al. (2013), and Lu and Chueh (2015).

\subsubsection{The Effect of Corporate Social Responsibility on the Corporate Financial} Performance mediated by the level of Information Asymmetry

According to the results of the fourth hypothesis testing, the relationship between CSR on the CFP mediated by the level of IA showed a path coefficient value of 0.043 with $t-$ value of 3.829. This indicates that CSR had a positive and significant effect on the CFP mediated by the level of IA, supporting the fourth hypothesis stating that the effect of CSR practices on CFP is mediated by the level of IA. The positive path coefficient of 0.043 indicates that CSR practices will improve CFP mediated by IA.

\subsection{Results}

\subsubsection{Hypothesis Testing}

Table 7

The test results with bootstrapping of the PLS analysis are as follows:

Path Analysis

\begin{tabular}{lcccccc}
\hline & $\begin{array}{c}\text { Original } \\
\text { Sample }\end{array}$ & $\begin{array}{c}\text { Sample } \\
\text { Mean }\end{array}$ & $\begin{array}{c}\text { Standard } \\
\text { Deviation }\end{array}$ & $\begin{array}{c}\text { t- } \\
\text { statistics }\end{array}$ & Value & Decision \\
\hline 1. CSR $\rightarrow$ CFP & 0.259 & 0.256 & 0.049 & 5.252 & 0.000 & Accepted \\
2. CSR $\rightarrow$ IA & -0.216 & -0.218 & 0.045 & 4.793 & 0.000 & Accepted \\
3. IA $\rightarrow$ CFP & -0.198 & -0.196 & 0.040 & 4.827 & 0.000 & Accepted \\
4. CSR $\rightarrow$ IA $\rightarrow$ CFP & 0.043 & 0.042 & 0.011 & 3.829 & 0.000 & Accepted \\
\hline
\end{tabular}

Source: data processed 2019.

According to Table 7 above, the results obtained are as follows:

1) The results of the first hypothesis testing suggest that the relationship between the CSR (X) and the CFP (Y) obtained a path coefficient value of 0.259 with t-value of 5.252. The value was greater than the tabulated $t$ ( $t$-table) of 1.960 , indicating that the CSR (CSR) had a positive and significant effect on the CFP. This is consistent with the first hypothesis stating that CSR practices are positively associated with CFP. Thus, hypothesis 1 was accepted. 
2) The results of the Second hypothesis testing suggest that the relationship between the CSR $(\mathrm{X})$ and the IA (M) obtained a path coefficient value of -0.216 with $\mathrm{t}$-value of 4.793. The value was greater than the tabulated $t(t$-table) of 1.960, indicating that the CSR (X) had a negative and significant effect on the IA (M). This is consistent with the second hypothesis stating that CSR practices are negatively associated with the level of IA. Thus, hypothesis 2 was accepted.

3) The results of the Third hypothesis testing suggest that the relationship between the CSR $(\mathrm{X})$ and the CFP $(\mathrm{Y})$ mediated by the level of IA $(\mathrm{M})$ obtained a path coefficient value of 0.043 with $\mathrm{t}$-value of 3.829 . The value was greater than the tabulated $\mathrm{t}(\mathrm{t}$ table) of 1.960, indicating that the CSR had a positive and significant effect on the CFP is mediated by the level of IA. This is consistent with the third hypothesis stating that the effect of CSR practices on CFP is mediated by the level of IA. Thus, hypothesis 3 was accepted.

4) Also, the results show that the relationship between the Information Asymmetry (M) and the Corporate Financial Performance $(\mathrm{Y})$ obtained a path coefficient value of 0.198 with $t$-value of 4.827 . The value was greater than the tabulated $t$ ( $t$-table) of 1.960, indicating that the Information Asymmetry had a negative and significant effect on the corporate financial performance.

Figure 3

Structural Model

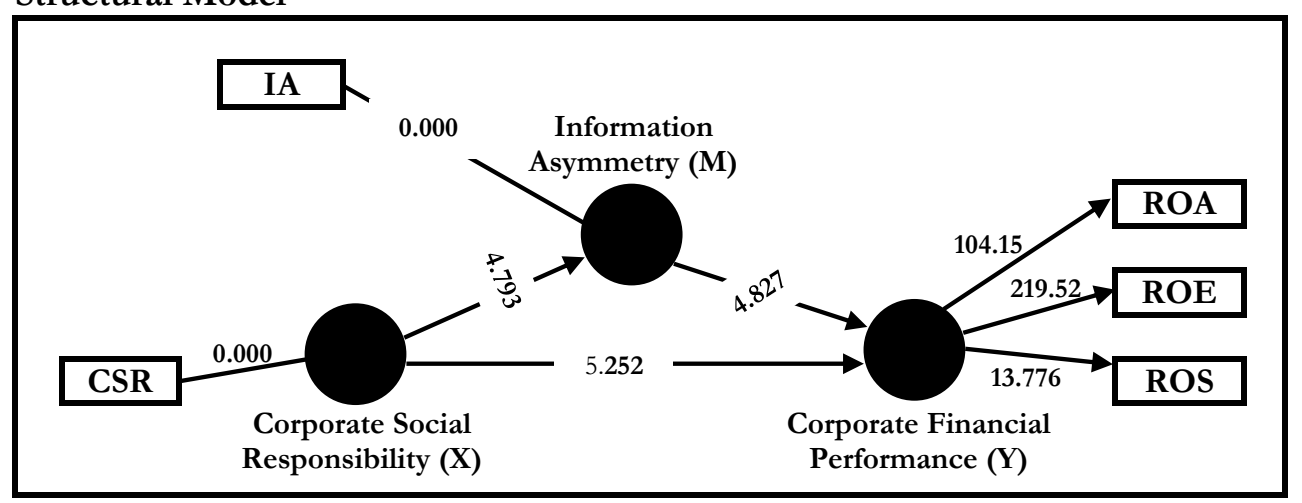

\section{CONCLUSION, LIMITATION AND FUTURE RESEARCH}

\subsection{Conclusion}

This study was conducted in order to improve CFP of Egyptian listed companies through; first, examining the direct effect of CSR on IS; second, to investigate the relationship between CSR and CFP; third, to examine the mediator role of IA in the relationship between CSR and CFP of Egyptian listed companies. Table 8 summarized research hypotheses and their results.

Insert Table 8 here.

Statistical analysis showed that there is a negative relationship between CSR and IA. This result supports theoretical arguments that companies engaged in CSR activities have low IA (Gelb \& Strawser, 2001; Cho et al., 2013; Lu \& Chueh, 2015; and Cui et al., 2018). This could be justified due to the growing and global awareness of the role of the companies in the society. Companies are trying to be more responsible for their stakeholders, rather than for their stockholders only. By doing so, companies build and maintain good reputation, which in turn mitigates IA. 
Table 8

\section{Hypotheses Acceptance}

\section{Hypotheses}

Accepted/Rejected

$\mathbf{H}_{1}$ : corporate social responsibility (CSR) practices are positively associated with corporate financial performance (CFP).

$\mathbf{H}_{2}$ : corporate social responsibility (CSR) practices are negatively associated with the level of information asymmetry (IA).

$\mathbf{H}_{3}$ : the effect of corporate social responsibility (CSR) practices on corporate financial performance (CFP) is mediated by the level of information asymmetry (IA).

Accepted

Accepted

Accepted

The results showed that CSR has a positive significant relation with CFP. This is consistent with Griffin and Mahon (1997), Verschoor (1998), Simpson and Kohers (2002), Samy et al. (2010), Sun (2012), Boesso et al. (2015), and Lu et al. (2018). The results argued that more socially responsible firms have stronger financial performance. This could be justified because CSR can have many positive impacts on enhancing the reputation of a company and allowing companies a unique selling point over their competitors. Moreover, CSR increases a firm's productivity by increasing employees' confidence and improving organizational solidarity.

\subsection{Limitation and Future Research}

Like most research of its kind, the results of the study are subject to several limitations. One potential limitation of the current study is the use of one measure for IA. Future research could use other measures as: bid-ask spread, PIN score and stock return volatility. Another limitation of the study is that our analysis is limited to a sample of Egyptian listed companies. Further research may investigate differences between the private and public sector in terms of CSR practices and in emerging countries. In addition, future research may perform longitudinal studies that investigate the improvement in organizational performance before and after the implementation of CSR activities. Finally, the possibility and implications of additional variables that may affect the relationship between CSR and CFP must be explored such as internal controls, corporate governance or cost of capital, especially in the developing countries.

\section{REFERENCES}

Abad, D., Cutillas-Gomariz, M. F., Sánchez-Ballesta, J. P., \& Yagüe, J. (2018). Does IFRS mandatory adoption affect information asymmetry in the stock market? Australian Accounting Review, 28(1), 61-78. Https://doi.org/ 10.1111/auar.12165.

Bartov, E., \& Bodnar, G. M. (1996, July). Alternative accounting methods, information asymmetry and liquidity: Theory and evidence. The Accounting Review, 71(3), 397418. Https://www.jstor.org/stable/248295?seq=1\#page_scan_tab_contents.

Becchetti, L., Ciciretti, R., Hasan, I., \& Kobeissi, N. (2012). Corporate social responsibility and shareholder's value. Journal of Business Research, 65(11), 16281635. Https://doi.org/10.1016/j.jbusres.2011.10.022.

Bhalla, R. (2013, February). CSR and reporting by selected Indian companies: An exploration. Prabandhan Indian Journal of Management, 6(1), 40-48. DOI: $10.17010 /$ pijom/2013/v6i1/59956. 
Boesso, G., Favotto, F., \& Michelon, G. (2015). Stakeholder prioritization, strategic corporate social responsibility and company performance: Further evidence. Corporate Social Responsibility \& Environmental Management, 22(6), 424440. Https://doi.org/10.1002/csr.1356.

Carroll, A. B. (1991). The pyramid of corporate social responsibility: Toward the moral management of organizational stakeholders. Business Horizons, 34(4), 39-48. Https://ideas.repec.org/a/eee/bushor/v34y1991i4p39-48.html.

Chan, H. W., \& Faff, R. W. (2003). An investigation into the role of liquidity in asset pricing: Australian evidence. Pacific-Basin Finance Journal, 11(5), 555-572. Https://doi.org/10.1016/S0927-538X(03)00003-9.

Cho, S. Y., Lee, C., \& Pfeiffer Jr., R. J. (2013, January-February). Corporate social responsibility performance and information asymmetry. Journal of Accounting \& Public Policy, 32(1), 71-83. Https://doi.org/10.1016/j.jaccpubpol.2012.10.005.

Cochran, P. L., \& Wood, R. A. (1984). Corporate social responsibility and financial performance. Academy of Management Journal, 27(1), 42-56. Https://doi.org/10.5465/255956.

Cohen, J., Holder-Webb, L., Nath, L., \& Wood, D. (2011). Retail investors' perceptions of the decision-usefulness of economic performance, governance, and corporate social responsibility disclosures. Behavioral Research in Accounting, 23(1), 109-129. Https://doi.org/10.2308/bria.2011.23.1.109.

Cruise, S. (2011). Investors demand improved sustainability reporting. Retrieved February 22, 2011, from Https://www.reuters.com/article/investors-sustainability/investorsdemand-improved-sustainability-reporting-idUSLDE71K0W120110221.

Cui, J., Jo, H., \& Na, H. (2018). Does corporate social responsibility affect information asymmetry? Journal of Business Ethics, 148(3), 549-572. Https://doi.org/ 10.2308/bria.2011.23.1.109.

El-Shayeb, N. A. (2016). Measuring the relationship between corporate social responsibility and earnings quality and their implications on stock performance. Unpublised master's thesis, submitted to Accounting Department, Faculty of Commerce, Cairo University, Egypt. In Partial Fulfilment of the Requirements of the Degree of Doctor of Philosophy in Accounting.

Fieseler, C. (2011, March). On the corporate social responsibility perceptions of equity analysts. Business Ethics: A European Review, 20(2), 131-147. Https://doi.org/ 10.1111/j.1467-8608.2011.01616.x.

Garg, P. (2016). CSR and corporate performance: Evidence from India. Decision, 43(4), 333-349.

Gelb, D. S., \& Strawser, J. A. (2001). Corporate social responsibility and financial disclosures: An alternative explanation for increased disclosure. Journal of Business Ethics, 33(1), 1-13.

Griffin, J. J., \& Mahon, J. F. (1997). The corporate social performance and corporate financial performance debate: Twenty-five years of incomparable research. Business \& Society, 36(1), 5-31. Https://doi.org/10.1177/ 000765039703600102.

Islam, Z., Ahmed, S., \& Hasan, I. (2012). Corporate social responsibility and financial performance linkage: Evidence from the banking sector of Bangladesh. Journal of Organizational Management, 1(1), 14-21. Https://papers.ssrn.com/sol3/ papers.cfm?abstract_id=1999140.

Leuz, C., \& Verrecchia, R. E. (2000). The economic consequences of increased disclosure. Journal of Accounting Research, 38, 91-124. DOI: 10.2307/2672910. 
Lu, C.-W., \& Chueh, T.-S. (2015). Corporate social responsibility and information asymmetry. Journal of Applied Finance \& Banking, 5(3), 105-122.

Lu, W., Ye, M., Chau, K. W., \& Flanagan, R. (2018). The paradoxical nexus between corporate social responsibility and sustainable financial performance: Evidence from the international construction business. Corporate Social Responsibility \& Environmental Management. Https://doi.org/10.1002/csr.1501

Matin, Y. A., Thaghafian, H., Esapour, K., Alavi, M. A., \& Farhoodi, A. (2011). A study of the relationship between corporate social responsibility and firm financial performance. Australian Journal of Basic \& Applied Sciences, 5(12), 668-674. Https://pdfs.semanticscholar.org/d7e8/b6acaf6ad0e4f24079ccdcc9c5f8350ca31 0.pdf.

McWilliams, A., \& Siegel, D. (2000). Corporate social responsibility and financial performance: Correlation or misspecification? Strategic Management Journal, 21(5), 603-609. Https://doi.org/10.1002/(SICI)1097-0266(200005)21:5<603::AID$\mathrm{SMJ} 101>3.0 . \mathrm{CO} ; 2-3$.

Nelling, E., \& Webb, E. (2009). Corporate social responsibility and financial performance: The "virtuous circle" revisited. Review of Quantitative Finance \& Accounting, 32(2), 197-209. Https://link.springer.com/article/10.1007/s11156008-0090-y.

Nollet, J., Filis, G., \& Mitrokostas, E. (2016, January). Corporate social responsibility and financial performance: A non-linear and disaggregated approach. Economic Modelling, 52(B), 400-407. Https://doi.org/10.1016/j.econmod.2015.09.019.

Peloza, J., \& Shang, J. (2011, February). How can corporate social responsibility activities create value for stakeholders? A systematic review. Journal of the Academy of Marketing Science, 39(1), 117-135.

Petersen, C., \& Plenborg, T. (2006). Voluntary disclosure and information asymmetry in Denmark. Journal of International Accounting, Auditing \& Taxation, 15(2), 127-149. Https://doi.org/10.1016/j.intaccaudtax.2006.08.004.

Razek, M. A. (2014). The association between corporate social responsibility disclosure and corporate governance: A survey of Egypt. Research Journal of Finance \& Accounting, 5(1), 93-98.

Relch, R. B. (1998). The new meaning of corporate social responsibility. California Management Review, 40(2), 8-17.

Rodriguez-Fernandez, M. (2016). Social responsibility and financial performance: The role of good corporate governance. BRQ Business Research Quarterly, 19(2), 137 151. Https://doi.org/10.1016/j.brq.2015.08.001.

Samy, M., Odemilin, G., \& Bampton, R. (2010, April). Corporate social responsibility: A strategy for sustainable business success. An analysis of 20 selected British companies. Corporate Governance The International Journal of Business in Society, 10(2), 203-217. Https://doi.org/10.1108/14720701011035710.

Saxena, M., \& Kohli, A. S. (2012). Impact of corporate social responsibility on corporate sustainability: A study of the Indian banking industry. IUP Journal of Corporate Governance, 11(4), 35-52. Http://www.indianjournals.com/ ijor. aspx? target $=$ ijor:ijmss\&volume $=3 \&$ issue $=8 \&$ article $=004$.

Simpson, W. G., \& Kohers, T. (2002). The link between corporate social and financial performance: Evidence from the banking industry. Journal of business etbics, 35(2), 97-109. Https://link.springer.com/article/10.1023/A:1013082525900. 
Sun, L. (2012). Further evidence on the association between corporate social responsibility and financial performance. International Journal of Law \& Management, 54(6), 472-484. Https://doi.org/10.1108/17542431211281954.

Sundaralingam, Y., \& Yazdanifard, R. (2014, September). What promotes a company to get involved in corporate social responsibility in current days? Retrieved September, 2014, from https://www.researchgate.net/publication/265989420_WHAT_ PROMOTES_A_COMPANY_TO_GET_INVOLVED_IN_CORPORATE_S OCIAL_RESPONSIBILITY_IN_CURRENT_DAYS.

Verschoor, C. C. (1998). A study of the link between a corporation's financial performance and its commitment to ethics. Journal of Business Ethics, 17(13), 15091516. Https://link.springer.com/article/10.1023/A:1006020402881. 